Check for updates

Cite this: Chem. Sci., 2019, 10, 1634

๑ All publication charges for this article have been paid for by the Royal Society of Chemistry

Received 19th October 2018

Accepted 27th November 2018

DOI: $10.1039 / \mathrm{c} 8 \mathrm{sc} 04660 \mathrm{c}$

rsc.li/chemical-science

\title{
A catalytic antioxidant for limiting amyloid-beta peptide aggregation and reactive oxygen species generation $\dagger$
}

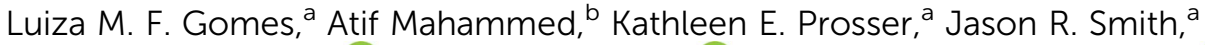 \\ Michael A. Silverman, (D) Charles J. Walsby, (D) ${ }^{\text {a }}$ Zeev Gross ${ }^{\star b}$ and Tim Storr (DD *a
}

\begin{abstract}
Alzheimer's disease (AD) is a multifaceted disease that is characterized by increased oxidative stress, metalion dysregulation, and the formation of intracellular neurofibrillary tangles and extracellular amyloid- $\beta$ (A $\beta$ ) aggregates. In this work we report the large affinity binding of the iron(III) 2,17-bis-sulfonato-5,10,15tris(pentafluorophenyl)corrole complex FeL1 to the $A \beta$ peptide $\left(K_{d} \sim 10^{-7}\right)$ and the ability of the bound FeL1 to act as a catalytic antioxidant in both the presence and absence of $\mathrm{Cu}(॥)$ ions. Specific findings are that: (a) an A $\beta$ histidine residue binds axially to FeL1; (b) that the resulting adduct is an efficient catalase; (c) this interaction restricts the formation of high molecular weight peptide aggregates. UV-Vis and electron paramagnetic resonance (EPR) studies show that although the binding of FeL1 does not influence the $\mathrm{A} \beta-\mathrm{Cu}(\|)$ interaction $\left(K_{\mathrm{d}} \sim 10^{-10}\right)$, bound FeL1 still acts as an antioxidant thereby significantly limiting reactive oxygen species (ROS) generation from A $\beta-\mathrm{Cu}$. Overall, FeL1 is shown to bind to the $A \beta$ peptide, and modulate peptide aggregation. In addition, FeL1 forms a ternary species with $\mathrm{A} \beta-\mathrm{CU}(\mathrm{II})$ and impedes ROS generation, thus showing the promise of discrete metal complexes to limit the toxicity pathways of the $A \beta$ peptide.
\end{abstract}

\section{Introduction}

Alzheimer's disease (AD) is the most common form of dementia, representing between $50-75 \%$ of all cases. ${ }^{1}$ In 2017 , an estimated 50 million people worldwide suffered from dementia, and this number is projected to grow sharply due to increased life expectancy. ${ }^{2}$ The lack of effective treatment strategies for $\mathrm{AD}$, coupled with increased incidence, has stimulated extensive research efforts in this important field. ${ }^{3}$

Clinical diagnosis of $\mathrm{AD}$ is currently based on progressive loss of memory and impairment in cognition, ${ }^{4}$ with final diagnosis requiring post-mortem examination of the brain to determine the severity of two neuropathological hallmarks; amyloid- $\beta$ (A $\beta$ ) plaques and neurofibrillary tangles (NFTs). It is still unclear whether $A \beta$-plaques, NFTs, or both, are a cause or an effect of the neurodegeneration in $\mathrm{AD} .^{5}$ NFTs are intracellular aggregates of oxidatively-modified and hyperphosphorylated microtubule-associated protein tau, ${ }^{6}$ while $\mathrm{A} \beta$

\footnotetext{
${ }^{a}$ Department of Chemistry, Simon Fraser University, V5A-1S6, Burnaby, BC, Canada. E-mail: tim_storr@sfu.ca

${ }^{b}$ Schulich Faculty of Chemistry, Technion-Israel Institute of Technology, Haifa, 32000, Israel.E-mail:chr10zg@technion.ac.il

${ }^{c}$ Department of Biological Sciences, Simon Fraser University, V5A-1S6, Burnaby, BC, Canada
}

$\dagger$ Electronic supplementary information (ESI) available. See DOI: $10.1039 / \mathrm{c} 8 \mathrm{sc} 04660 \mathrm{c}$ plaques are extracellular and contain the $A \beta$ peptide as the major constituent. The $A \beta$ peptide is a product of the amyloid precursor protein (APP), and a series of cleavage events by $\alpha-, \beta-$, $\gamma$-secretases, ${ }^{7}$ afford the $A \beta$ peptide as predominantly $A \beta_{1-40}$ or $A \beta_{1-42}$ (a 40- or 42-residue peptide). ${ }^{8}$ In addition, truncation at the N-terminus results in $\mathrm{A} \beta_{3(\mathrm{p})-n}, \mathrm{~A} \beta_{4-n}$, and $\mathrm{A} \beta_{11(\mathrm{p})-n}$ (where $\mathrm{p}$ refers to pyroglutamate) peptides that are also significant components of amyloid deposits. ${ }^{9} \mathrm{~A} \beta$ can be found in three general forms in the brain: membrane associated, aggregated, and soluble. Most of $\mathrm{A} \beta$ is membrane-associated in healthy individuals, but in individuals with $\mathrm{AD}$ the aggregated and soluble fractions increase considerably. ${ }^{\mathbf{8 , 1 0}}$

Early neuronal and pathological changes show indications of oxidative damage, indicating oxidative stress is involved in $\mathrm{AD} .{ }^{\mathbf{1 1}}$ The cause of oxidative stress in $\mathrm{AD}$ has been attributed to a number of factors, including impaired cellular energy metabolism and/or Fenton-type processes involving redoxactive metal-ions (Fe, $\mathrm{Cu}$ ), and metal-containing aggregates. ${ }^{\mathbf{1 2}}$ Metal-ions, such as $\mathrm{Zn}, \mathrm{Cu}$ and $\mathrm{Fe}$, are essential for healthy organisms and brain function, and are tightly regulated under normal circumstances. ${ }^{13}$ However, a change in metal-ion homeostasis in the brain has been associated with protein aggregation, and the generation of reactive oxygen species (ROS) in neurodegenerative diseases such as $\mathrm{AD} .{ }^{\mathbf{1 4}}$ Metal-ions are present in increased concentrations in $A \beta$ plaques in comparison to normal brain tissue, with concentrations of $c a$. $0.4 \mathrm{mM}$ for $\mathrm{Cu}, 1 \mathrm{mM}$ for $\mathrm{Zn}$, and $0.9 \mathrm{mM}$ for Fe. ${ }^{13 a, 13 b, 15}$ Metal- 
ion binding can modify the aggregation pattern of $\mathrm{A} \beta$, disrupt normal metalloenzyme activity, and facilitate the production of ROS. ${ }^{10 b, \mathbf{1 4 a}, \mathbf{1 4 c , 1 6}}$ Recent studies have shown that the $\mathrm{A} \beta-\mathrm{Cu}(\mathrm{II})$ complex exhibits detrimental catalytic ROS generation, particularly so in the presence of cholesterol and vitamin $\mathrm{C}$, and is able to reduce $\mathrm{O}_{2}$ generating the superoxide anion $\left(\mathrm{O}_{2}{ }^{-}\right)$, hydrogen peroxide $\left(\mathrm{H}_{2} \mathrm{O}_{2}\right)$, and hydroxyl radical $(\cdot \mathrm{OH}) .{ }^{17}$

As a result of the possible role of metal-ion dyshomeostasis in $\mathrm{AD}$, the development of multifunctional metal binding molecules as therapeutics has been actively explored. ${ }^{18} \mathrm{We}$, and others, have developed metal-binding agents with additional properties such as radical scavenging, peptide binding and aggregation inhibition, and acetylcholine esterase (AChE) activity. ${ }^{19}$ In addition, a number of groups have explored the use of discrete metal complexes for the diagnosis and treatment of $\mathrm{AD} .^{20}$ In terms of therapeutics, $\mathrm{Pt},{ }^{21} \mathrm{Ru},{ }^{22} \mathrm{Ir},{ }^{23} \mathrm{Co},{ }^{10 b, 24} \mathrm{Re},{ }^{25} \mathrm{Rh},{ }^{26}$ $\mathrm{Mn},{ }^{27}$ and $\mathrm{V}^{28}$ complexes have been investigated for their ability to modify the aggregation of the $A \beta$ peptide, and certain compounds have shown promising results in disease models. For example, an orally-available Pt(Iv) complex (Scheme 1) was shown to cross the blood-brain barrier (BBB), reduce plaque burden, and reduce $A \beta$ peptide levels in a APP/Ps1 mouse model. ${ }^{29}$ Therefore, a metal complex that can bind to the $A \beta$ peptide, modulate aggregation, and reduce ROS production is a promising therapeutic for $\mathrm{AD}$.

Corrole ligands are known to bind to metal ions, such as $\mathrm{Al}$, $\mathrm{Cu}, \mathrm{Fe}, \mathrm{Ga}$, and $\mathrm{Au}$, and the corresponding metal complexes display outstandingly high hydrolytic stability. ${ }^{30}$ The iron(III) complex (FeL1, Scheme 1) displays excellent catalase activity, ${ }^{31}$ superoxide dismutase (SOD) activity, ${ }^{30 a}$ and catalytic activity for the decomposition of peroxynitrite $\left(\mathrm{PN}, \mathrm{ONOO}^{-}\right) \cdot{ }^{\mathbf{3 0 d}, 32}$ Additionally, FeL1 binds to and protects the cholesterol-carrying lipoproteins from oxidative stress; and oral administration of FeL1 to a mouse model of atherosclerosis leads to a decrease in atherosclerotic lesions. ${ }^{30 c, 33}$ We were thus interested to investigate the interaction of FeL1 with the A $\beta$ peptide, and how this would modulate peptide aggregation and ROS generation. Strong inspiration came from reports by Dey et al., who have shown that heme binds to the $A \beta$ peptide, that one of the three histidine residues $\left(\mathrm{His}^{6}\right)$ of $A \beta$ is ligated to the heme's iron, and that the heme-A $\beta$ adduct induces ROS formation. ${ }^{17 a, 34}$ Furthermore, a study that focused on the uptake of iron complexes by macrophages, which are a major source of ROS, revealed that heme is cytotoxic while FeL1 is cytoprotective. ${ }^{35}$ Additionally, FeL1 was reported to have low cytotoxic activity while maintaining cell cycle distribution similar to untreated cancer cells. ${ }^{36}$
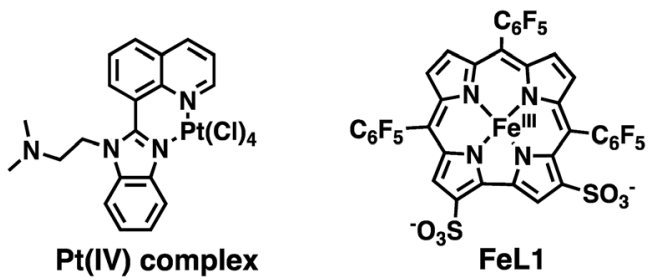

Scheme 1 Structures of Pt(IV) complex, and Fe(III) corrole (FeL1) complex.
We report the interaction of FeL1 with the A $\beta$ peptide, how it affects peptide aggregation, and the radical scavenging ability of the FeL1-A $\beta$ adduct, in both the presence and absence of $\mathrm{Cu}$ (II) ions.

\section{Results and discussion}

\section{Binding of $A \beta$ His residues to FeL1}

The Fe(III) complex of the amphipolar 2,17-bis-sulfonato5,10,15-tris(pentafluorophenyl)corrole (FeL1) has very strong affinity to human serum albumin (HSA) and lipoproteins, which is in part due to binding of histidine (His) residues to the metal ion. ${ }^{30 c, 37}$ The His ligation causes a shift in the Soret band of FeL1 from 390 to $410 \mathrm{~nm}$, as well as the formation of a new band at $620 \mathrm{~nm}$, and the intensity of the latter band is associated with the binding of either one or two axial His residues. ${ }^{30 c, 31,37}$ There are three $A \beta$ His residues (His ${ }^{6}, \mathrm{His}^{13}$, and His ${ }^{14}$ ) and they play an important role in metal-ion binding (Scheme 2), with dissociation constants $\left(K_{\mathrm{d}}\right)$ of $\sim 10^{-10} \mathrm{M}$ for $\mathrm{Cu}$ (II) and $\sim 10^{-5} \mathrm{M}$ for $\mathrm{Zn}(\mathrm{II}){ }^{10 b, \mathbf{1 4 a}, \mathbf{3 8}}$ In addition, $\mathrm{A} \beta$ His residues have been reported to bind to discrete metal complexes such as heme, ${ }^{34 a} \mathrm{Ru}$ complexes, ${ }^{\text {22a,23a,39 }}$ and Co complexes. ${ }^{\mathbf{1 0 b , 2 4}}$ In addition to His binding, residues $\mathrm{Asp}^{1}$, $\mathrm{Tyr}^{10}$, and $\mathrm{Glu}^{11}$ play a role in the coordination of $\mathrm{A} \beta$ to $\mathrm{Cu}(\mathrm{II})$ and $\mathrm{Zn}(\mathrm{II}){ }^{40}$

Prior to investigating the interaction(s) of FeL1 with the A $\beta$ peptide by UV-Vis spectroscopy, its binding to 1-methylimidazole (1-MeIm) was examined as to determine the spectral features and binding affinity associated with exogenous imidazole as the axial ligand. Gradual addition of up to 150 equiv. of 1-MeIm led to a shift in the near UV (Soret) band, a decrease in the band at $533 \mathrm{~nm}$, and the formation of a new band at $620 \mathrm{~nm}$ (Fig. 1). The spectral changes matched those for histidine binding (Fig. S1 $\dagger$ ), ${ }^{30 c}$ however in both cases a large excess of ligand is required (150 and 700 equiv. respectively) to observe spectral endpoints. A variable pH UV-Vis titration (Fig. S2 $\dagger$ ), at a concentration ratio of 1:2 FeL1 : 1-MeIm, together with subsequent data fitting using Hypspec and HySS, ${ }^{\mathbf{4 1 , 4 5}}$ provides binding constants of $\log \mathrm{M}(1-\mathrm{MeIm})=5.81 \pm 0.01$ (where $\mathrm{M}=$ FeL1) and a much smaller $\log \mathrm{M}(1-\mathrm{MeIm})_{2}=2.57 \pm 0.02$. Our results are in accord with the higher stability of 5-coordinate mono-axial ligated Fe(III) corroles in comparison to 6-coordinate bis-axial ligated $\mathrm{Fe}(\mathrm{III})$ corroles, ${ }^{42}$ which is opposite to that

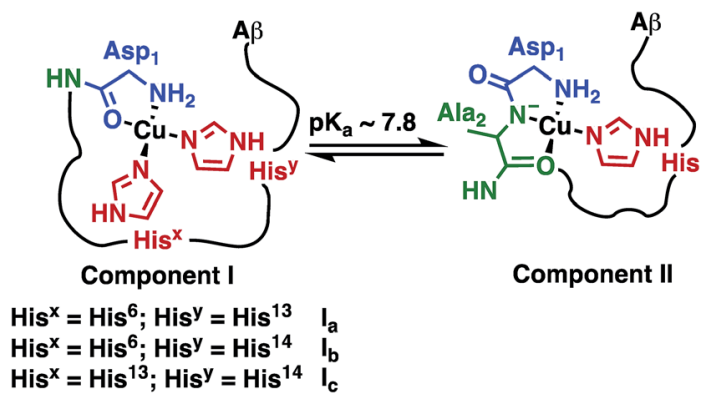

Scheme 2 Representation of Component I $\left(I_{a}, I_{b}, I_{c}\right)$ and Component II, the two major $\mathrm{pH}$-dependent $\mathrm{A} \beta-\mathrm{Cu}(\mathrm{I})$ binding modes (modified from Borghesani et al., 2018). ${ }^{9 c}$ 


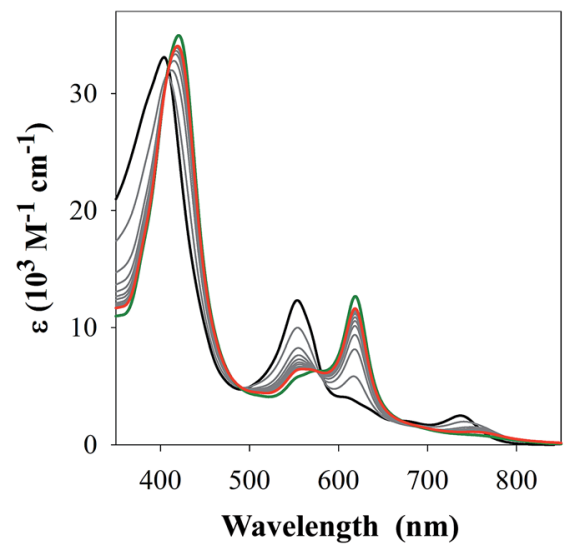

Fig. 1 UV-Vis spectra of 1-Melm additions to FeL1 (30 $\mu \mathrm{M}$, black) in PBS buffer ( $0.01 \mathrm{M}, \mathrm{pH} 7.4)$. Grey lines represent additions of 5 equiv. of 1-Melm up to 50 equiv. (red) with a maximum of absorption at $620 \mathrm{~nm}$ for 150 equiv. shown in green.

reported for $\mathrm{Fe}(\mathrm{III})$ porphyrins. ${ }^{43}$ The main reason for this difference is that upon bis-axial ligation $\mathrm{Fe}(\mathrm{III})$ porphyrins gain more crystal field stabilization energy (CFSE) as they transform from high spin (HS) to low spin (LS), while Fe(III) corroles only transform from intermediate spin (IS) to LS. ${ }^{42 b, 42 c}$

The studies with 1-MeIm provided critical information for examining the interaction of FeL1 with the full length $A \beta_{1-42}$ and two truncated peptides: $A \beta_{1-16}$ that contains the metal binding $\mathrm{N}$-terminus $\left(\mathrm{His}^{6}{ }^{6} \mathrm{His}^{13}\right.$, $\mathrm{His}^{14}$ ), and $\mathrm{A} \beta_{17-40}$ with the hydrophobic portion of the peptide lacking any His. Addition of $A \beta_{17-40}$ to FeL1 did not induce any significant spectral changes, while even a single equivalent of either $A \beta_{1-42}$ or $A \beta_{1-16}$ led to a red shift and intensity-increase of the Soret band, accompanied by the appearance of a $\lambda_{\max }=620 \mathrm{~nm}$ band (Fig. 2). While this experiment clearly proves the importance of His-Fe binding, the comparison of Fig. 2 and 1 exposes major differences. Importantly, the binding of the protein-provided histidine must be much stronger than that of 1-MeIm as full spectra changes are achieved with 1 vs. >100 equivalents, respectively.

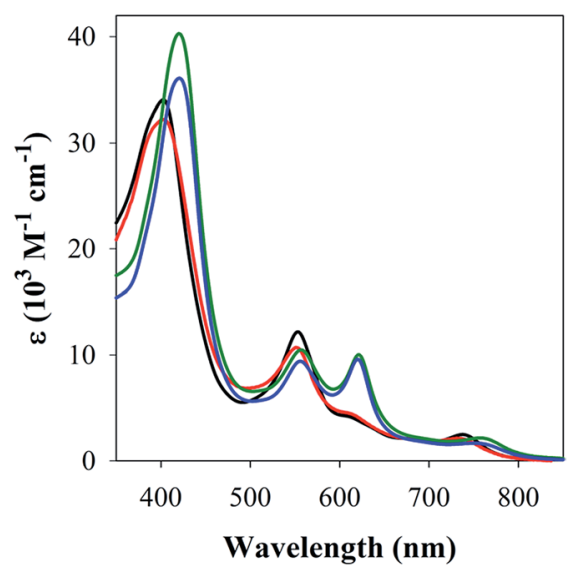

Fig. 2 UV-Vis spectra of FeL1 (30 $\mu \mathrm{M}$, black) in the presence of 1 equiv. of $A \beta_{17-40}$ (red), $A \beta_{1-16}$ (green) and $A \beta_{1-42}$ (blue) in PBS buffer (0.01 M, $\mathrm{pH} 7.4)$.
In the former case, the observed spectral changes occur immediately upon mixing, with no further spectral changes apparent after monitoring for $1 \mathrm{~h}$, and addition of excess $A \beta_{1-16}$ (up to 16 equivalents, Fig. S3†) did not induce further spectral changes. The last result is also highly relevant to the other spectral difference: while the $533 \mathrm{~nm}$ band disappears in the presence of a large excess of 1-MeIm (Fig. 1), the bands at 533 and $620 \mathrm{~nm}$ remain of essentially equal intensity starting from a $1: 1$ (Fig. 2) to a $1: 16$ (Fig. S3†) ratio of FeL1 : A $\beta_{1-16}$. Taken together, the results show that FeL1 and $A \beta$ form a $1: 1$ adduct that relies on only one of the His residues in $\mathrm{A} \beta$. The other two His residues are either too far away to approach the metal center and/or are unable to bind due to steric interference. Previous reports agree with our findings in that axial ligand binding to $\mathrm{Fe}(\mathrm{III})$ corroles shows that the 5-coordinate species is stabilized in comparison to the 6-coordinate bis-axial ligated species. $^{42 a, 42 b, 44}$

The stability of the $1: 1$ FeL1 : $A \beta_{1-16}$ adduct was determined via a variable $\mathrm{pH}$ titration (Fig. 3), which together with subsequent data fitting using Hypspec and HySS, ${ }^{41,45}$ provided binding constants of $\log \mathrm{M}\left(\mathrm{A} \beta_{1-16}\right)=11.90 \pm 0.01$, and
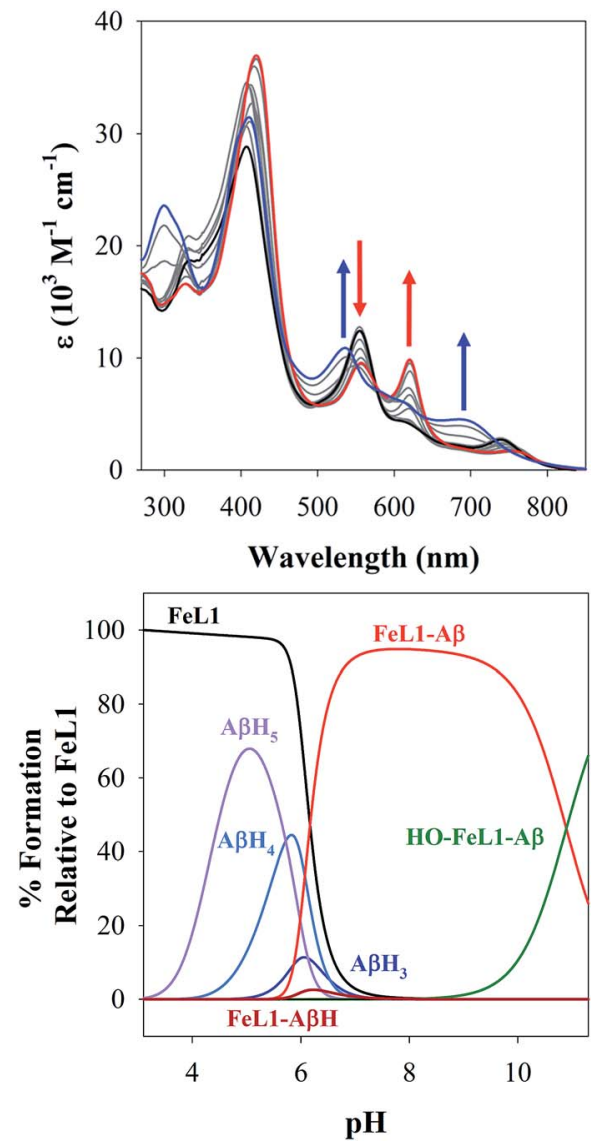

Fig. 3 (Top) variable pH UV-Vis titration of FeL1 $(30 \mu \mathrm{M})$ and $A \beta_{1-16}$ $(30 \mu \mathrm{M})$ from $\mathrm{pH} 3.1$ (black) to $\mathrm{pH} 11.5$ (blue). The red spectrum represents the maximum absorbance for the FeL1-A $\beta$ complex at $\mathrm{pH}$ 8.2. (Bottom) using HypSpec and HySS, ${ }^{41}$ the variable $\mathrm{pH}$ data were fitted to a model including FeL1-A $\beta$, FeL1-A $\beta(H)$, and a HO-FeL1-A $\beta$ component at high $\mathrm{pH}$. At $\mathrm{pH} 7.4$ the majority of FeL1 is bound to $A \beta_{1-16}(>99 \%)$. 
$\log \mathrm{M}\left(\mathrm{A} \beta_{1-16}\right)(\mathrm{H})=4.90 \pm 0.02$ (where $\mathrm{M}=$ FeL1, and $(\mathrm{H})$ indicates a mono-protonated peptide species). This experiment demonstrates the much higher affinity of FeL1 for the A $\beta$ peptide in comparison to 1-MeIm (see below). At higher $\mathrm{pH}$ values (>9.5) a metal hydrolysis species is evident (modelled as $\log \mathrm{M}\left(\mathrm{A} \beta_{1-16}\right)(\mathrm{OH})$, presumably due to deprotonation of a bound $\mathrm{H}_{2} \mathrm{O}$ ligand). As indicated from the speciation diagram (Fig. 3), the interaction of FeL1 with the A $\beta$ peptide coincides with His deprotonation (reported $\mathrm{p} K_{\mathrm{a}}$ values of $5.72,6.5$, and $6.95){ }^{46}$ Further analysis of the speciation diagram of FeL1 with $\mathrm{A} \beta_{1-16}$ provides the binding affinity at physiological $\mathrm{pH}$. The concentration of free FeL1 present in solution at a given $\mathrm{pH}$, referred to as $\mathrm{pM}\left(\mathrm{p}(\right.$ FeL1 $)=-\log \left[(\text { FeL1 })_{\text {unchelated }}\right)$, is a direct estimate of metal-ligand affinity when all species in solution are considered.$^{47}$ The calculated value for $\mathrm{p}($ FeL1) is 6.6 ([FeL1] $\left.=\left[\mathrm{A} \beta_{1-16}\right]=30 \mu \mathrm{M}\right)$, which affords a $K_{\mathrm{d}}$ value of $\sim 10^{-7} \mathrm{M} \cdot .^{18 a, 48}$ This value shows that the affinity of A $\beta$ for FeL1 is lower than for $\mathrm{Cu}(\mathrm{II})$ but larger than for $\mathrm{Zn}$ (II).

To gain more insight into the binding event, both ${ }^{1} \mathrm{H}$ NMR and ESI-MS studies were performed. The MS spectrum of a $1: 1$ FeL1 : A $\beta_{1-16}$ adduct showed multiple $m / z$ peaks consistent with FeL1 binding to $A \beta_{1-16}$, with the most intense adduct peak corresponding to $\left[\text { FeL1-A } \beta_{1-16}\right]^{2+}$ (Fig. S5†). FeL1 has been reported to bind to human serum albumin (HSA), ${ }^{31}$ and in addition the $A \beta$ peptide shows a specific interaction with HSA. ${ }^{49}$ Based on these reports we investigated the binding of FeL1 to A $\beta$ in the presence of HSA, and under these conditions observed the $\left[\text { FeL1-A } \beta_{1-16}\right]^{2+}$ adduct (Fig. S6 $\dagger$ ). The ${ }^{1} \mathrm{H}$ NMR of $\mathrm{A} \beta_{1-16}$ was recorded in the presence of 0.10 and 0.25 equivalents of the paramagnetic FeL1. ${ }^{\mathbf{1 0 b}, 50}$ Initially, the signals from the three histidines and the tyrosine were quite sharp and well resolved (Fig. 4, bottom trace). Addition of FeL1 induced broadening of all signals attributed to the histidines (7.95, 7.05, $7.00 \mathrm{ppm}$ ), while those of $\operatorname{Tyr}^{10}$ (7.10 and $6.82 \mathrm{ppm}$ ) were not affected (Fig. 4, mid and top traces). Overall, the data are consistent with binding of an $\mathrm{A} \beta$ His residue to FeL1, and there is likely no
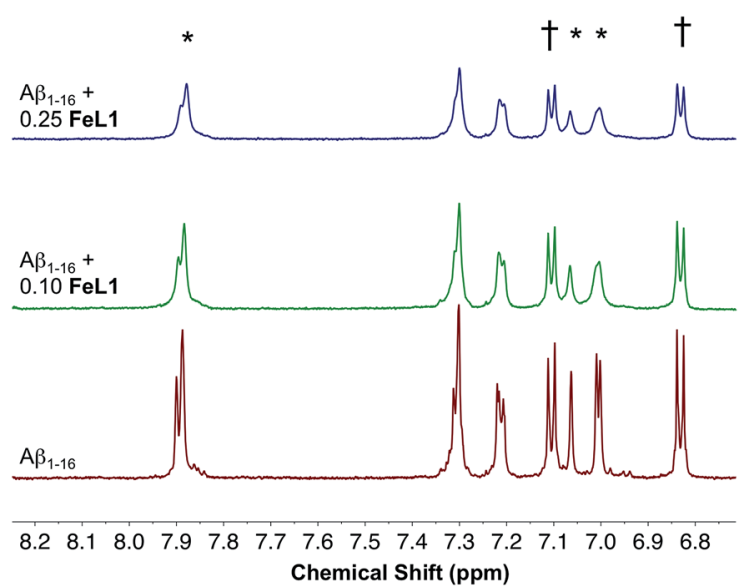

Fig. 4 Changes in the ${ }^{1} \mathrm{H}$ NMR spectra of $A \beta_{1-16}$ in the presence of FeL1. Shown are spectra obtained at $210 \mu \mathrm{M} \mathrm{A} \beta_{1-16}$, in PBS buffer prepared in $\mathrm{D}_{2} \mathrm{O} \mathrm{pH} 7.4$ at $25^{\circ} \mathrm{C}$ (red), with addition of 0.10 (green) and 0.25 equivalents (blue) of FeL1. ${ }^{*} \mathrm{His}^{6}, \mathrm{His}^{13}$, and $\mathrm{His}^{14}$. ${ }^{\dagger} \mathrm{Tyr}{ }^{10}$. preference for any of the available peptide His residues (His ${ }^{6}$, His $\left.^{13}, \operatorname{His}^{14}\right)$.

\section{FeL1 binding to $\mathrm{A} \beta$ in the presence of $\mathrm{Cu}(\mathrm{II})$}

UV-Vis analysis. The affinity between $\mathrm{Cu}(\mathrm{II})$ and $\mathrm{A} \beta$ is very large $\left(K_{\mathrm{d}}\right.$ of $\left.\sim 10^{-10} \mathrm{M}\right)$ and the inner coordination sphere of $\mathrm{Cu}(\mathrm{II})$ in the adduct is usually composed of the $\mathrm{N}$-terminal amine, one carbonyl group and two histidines (Scheme 2, Component I, major species at $\mathrm{pH}=7.4){ }^{10 b, 14 a, 38 a, 51}$ Although the affinity of FeL1 to A $\beta$ was found to be quite large $\left(K_{\mathrm{d}} \sim 10^{-7}\right.$ $\mathrm{M})$ it is still 3 orders of magnitude lower than that of $\mathrm{Cu}(\mathrm{II})$, and thus is not expected to compete for the $\mathrm{Cu}$ (II) binding site. Considering, however, that the $\mathrm{A} \beta-\mathrm{Cu}(\mathrm{II})$ adduct still has one His residue not involved in $\mathrm{Cu}$ binding, concurrent binding of $\mathrm{Cu}(\mathrm{II})$ and FeL1 to A $\beta$ is possible and of large potential interest. This aspect was addressed by combining FeL1 with a preformed $\mathrm{A} \beta-\mathrm{Cu}(\mathrm{II})$ complex and also vice versa, by adding $\mathrm{Cu}$ (II) to a FeL1/ peptide mixture. Identical results were obtained in both cases (Fig. 5 and $\mathrm{S} 4 \dagger$ ) and the corresponding UV-Vis spectra clearly revealed the earlier outlined spectral features associated with axial His binding. This shows that FeL1 binds to the peptide even in the presence of $\mathrm{Cu}(\mathrm{II})$ and also provides another independent indication that the inner coordination sphere of FeL1 has only one axial histidine ligand. The formation of the ternary adduct $\left(1: 1: 1 \quad\right.$ FeL1 $: \mathrm{A} \beta_{1-16}: \mathrm{Cu}$ adduct $)$ was further confirmed by ESI-MS, with $\mathrm{m} / \mathrm{z}$ peaks corresponding to [FeL1$\mathrm{A} \beta-\mathrm{Cu}(\mathrm{II})]^{2+}$ and sodium adducts (Fig. $\mathrm{S} 5 \dagger$ ).

EPR characterization. In order to better understand the binding of both $\mathrm{Cu}$ (II) and FeL1 to the $\mathrm{A} \beta$ peptide, we analyzed the electron paramagnetic resonance (EPR) spectra of $\mathrm{A} \beta_{1-16}-\mathrm{Cu}(\mathrm{II})$, FeL1-A $\beta_{1-16}$, and finally FeL1-A $\beta_{1-16}-\mathrm{Cu}(\mathrm{II})$. The EPR data for $\mathrm{A} \beta_{1-}$ ${ }_{16}-\mathrm{Cu}$ (II) are in agreement with previous reports; ${ }^{12 b, 50,52}$ and simulation of the EPR spectra indicate the existence of both Component I and Component II therein (Scheme 2 and Fig. S7†). The simulation parameters are detailed in Table 1, and an approximate intensity ratio of 0.6 : 0.4 for Component I : Component II at $\mathrm{pH}$ 7.4 is in agreement with the measured $\mathrm{p} K_{\mathrm{a}}$ value of $7.8 \pm 0.5$ (Scheme 2) via the Henderson-Hasselbalch equation. ${ }^{12 b, 50}$

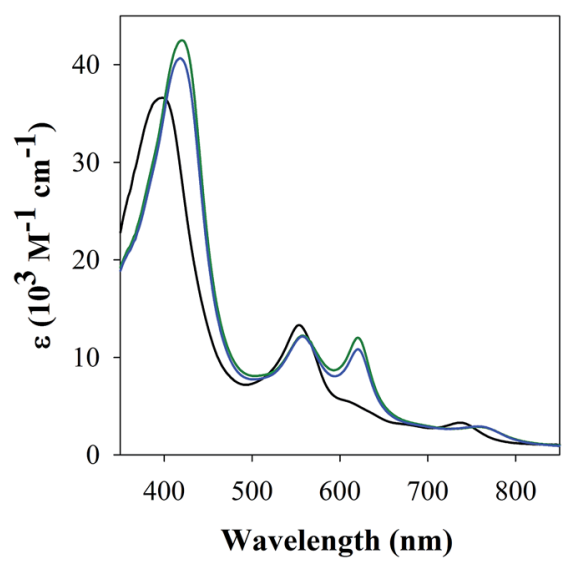

Fig. 5 UV-Vis spectra of binding of FeL1 $(30 \mu \mathrm{M}$, black) in PBS buffer $(0.01 \mathrm{M}, \mathrm{pH} 7.4)$ to 1 equiv. of $\mathrm{A} \beta_{1-16}$ with (blue) or without (green) $\mathrm{Cu}(॥)$ (0.9 equiv.). 
Table 1 X-band EPR simulation parameters ${ }^{a}$

\begin{tabular}{|c|c|c|c|c|c|c|c|c|c|c|c|c|c|}
\hline & \multicolumn{4}{|c|}{$\mathrm{A} \beta-\mathrm{Cu}(\mathrm{II})$ - Component I } & \multicolumn{4}{|c|}{$\mathrm{A} \beta-\mathrm{Cu}(\mathrm{II})-\mathrm{Component} \mathrm{II}$} & \multicolumn{2}{|c|}{$\begin{array}{l}\text { FeL1 } \\
(S=3 / 2)\end{array}$} & \multicolumn{3}{|c|}{ Fe bound $(S=1 / 2)$} \\
\hline & $g_{\|}$ & $g_{\perp}$ & $A_{\|}^{\mathrm{Cu}}$ & $\chi^{b}$ & $g_{\|}$ & $g_{\perp}$ & $A_{\|}^{\mathrm{Cu}}$ & $\chi^{b}$ & $g_{\|}$ & $g_{\perp}$ & $g_{1}$ & $g_{2}$ & $g_{3}$ \\
\hline $\mathrm{A} \beta-\mathrm{Cu}(\mathrm{II})$ & 2.26 & 2.05 & 186 & 0.6 & 2.22 & 2.05 & 170 & 0.4 & - & - & - & - & - \\
\hline FeL1 & - & - & - & - & - & - & - & - & 2.0 & 3.9 & - & - & - \\
\hline FeL1 MeIm & - & - & - & - & - & - & - & - & 2.0 & 3.9 & 2.70 & 2.2 & 1.8 \\
\hline FeL1-A $\beta$ & - & - & - & - & - & - & - & - & 2.0 & 3.9 & 2.75 & 2.2 & 1.7 \\
\hline FeL1-A $\beta-\mathrm{Cu}(\mathrm{II})$ & 2.26 & 2.05 & 186 & 0.7 & 2.22 & 2.05 & 170 & 0.3 & 2.0 & 3.9 & 2.75 & 2.2 & 1.7 \\
\hline
\end{tabular}

${ }^{a}$ See experimental section for details. ${ }^{b}$ Component relative abundance.

FeL1 in buffer displays a weak intermediate-spin Fe(III) signal at $g_{\perp}=3.9$ and $g_{\|}=2.0,,^{42 b, 53}$ whereas FeL1-A $\beta_{1-16}$ shows, in addition to this signal, also a rhombic spin system consistent with low-spin Fe(III) $S=\frac{1}{2}$ species (Table 1 and Fig. S8 $\dagger$ ). The latter is similar to the spectrum for FeL1 in the presence of 20 equiv. of 1-MeIm (Fig. S8 $\dagger$ ) and to reported EPR data for other 6coordinate low spin $\mathrm{Fe}$ (III) corroles (with $\mathrm{CN}^{-}$and pyridine as axial ligands). ${ }^{54}$ These data are consistent with contributions from both mono- and bis-axial ligated FeL1 in the EPR experiment, likely due to the increased ligand affinity upon freezing the solutions for EPR analysis. Increased bis-axial ligation to FeL1 is observed for both 1-MeIm and $A \beta_{1-16}$ in solution at lower temperatures $\left(10^{\circ} \mathrm{C}\right)$ by UV-Vis (Fig. S10 $\dagger$ ), and freezing a 5-coordinate (OEC)Fe(III)(py) corrole (OEC = trianion of $2,3,7,8,12,13,17,18$-octaethylcorrole) in pyridine results in a similar spectral pattern with both intermediate and low spin signals. ${ }^{\mathbf{4 2 b}}$ Due to the distinct temperature-dependence of signal intensity for the EPR spectra of the Fe species it is not possible to accurately determine their ratios from these experiments. ${ }^{55}$

Incubation of both $\mathrm{Cu}(\mathrm{II})$ and FeL1 with $\mathrm{A} \beta_{1-16}$ affords the ternary species FeL1-A $\beta_{1-16}-\mathrm{Cu}$ (II) with an EPR spectrum that is essentially the sum of the components $A \beta_{1-16}-\mathrm{Cu}(\mathrm{II})$ and FeL1$\mathrm{A} \beta_{1-16}$ (Fig. 6). The simulation parameters are detailed in Table 1 , with the two $\mathrm{Cu}$ (II) species Component I and Component II in a $0.7: 0.3$ ratio. While this differs slightly from the ratio for $\mathrm{A} \beta_{1-}$ ${ }_{16}-\mathrm{Cu}$ (II) alone, the limited resolution of the spectra suggests minimal change to the Cu-site upon binding of FeL1 to the peptide (vide infra). Similarly, the simulation parameters for the Fe species present in FeL1-A $\beta_{1-16}-\mathrm{Cu}$ (II) (Table 1) are identical to FeL1-A $\beta_{1-16}$ suggesting that while both $\mathrm{Cu}(\mathrm{II})$ and FeL1 bind to $A \beta_{1-16}$, the binding sites are independent of one another as far as can be determined through the EPR experiments. This is reminiscent of reported EPR analysis of $\mathrm{Cu}(\mathrm{II})$ and heme with $A \beta_{1-16}$, which also suggested that while both did bind to the peptide there was no observable interaction between the two metal centres. ${ }^{17 a}$

\section{Influence of FeL1 on A $\beta$ aggregation}

Gel electrophoresis and western blotting, in combination with Transmission Electron Microscopy (TEM), were used to investigate if binding of FeL1 to the $A \beta$ peptide would alter the size distribution of $A \beta$ species and the morphology of the resulting aggregates. The longer $\mathrm{A} \beta_{1-42}$ peptide was employed for this study, as it is most aggregation prone and neurotoxic. ${ }^{\mathbf{1 3 b , 5 6}}$ Incubation with low concentrations of FeL1 ( 0.1 to 1 equiv., for $24 \mathrm{~h}$ ) significantly affected the aggregation pattern (Fig. 7A). While the $A \beta_{1-42}$ peptide forms mostly high molecular weight aggregates (lane 1) in the absence of FeL1, consistent with previous reports, ${ }^{19 a, 24 b, 57}$ FeL1 exhibits a concentrationdependent effect on the aggregation pattern (lanes 2-5). Only low molecular weight species were observed after $24 \mathrm{~h}$ with one equiv. of FeL1 (lane 5). The influence of FeL1 on $A \beta_{1-42}$ aggregation was further confirmed by TEM (Fig. 7B-D). The TEM image for peptide alone shows long fibrils and large aggregate size, matching previous reports. ${ }^{24 b, 57}$ However, as the

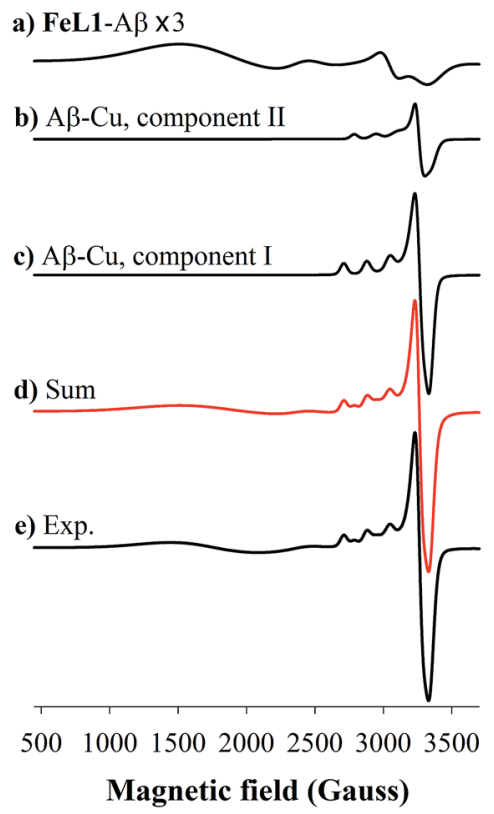

Fig. 6 Frozen-solution EPR spectrum (bottom), corresponding simulation (red) and spectral deconvolution of FeL1 in the presence of 1 equiv. of both $A \beta_{1-16}$ and $C u(I)$ at 20 K. (a) FeL1-A $\beta$ component simulation (multiplied by a factor of 3), (b) $A \beta-C u(॥)$ Component II simulation (c) $A \beta-C u(॥)$ Component I simulation (d) sum of all simulated species and (e) experimental spectrum. Conditions: $\left[A \beta_{1-16}\right]=$ $550 \mu \mathrm{M},[\mathrm{FeL} 1]=[\mathrm{Cu}(\mathrm{I})]=500 \mu \mathrm{M}$, in PBS buffer (0.05 M, pH 7.4). EPR parameters: frequency $=9.38 \mathrm{GHz}$, microwave power $=2.0 \mathrm{~mW}$, time constant $=40.96 \mathrm{~ms}$, modulation amplitude $=5 \mathrm{G}$, average of five 1 min scans. 
A)

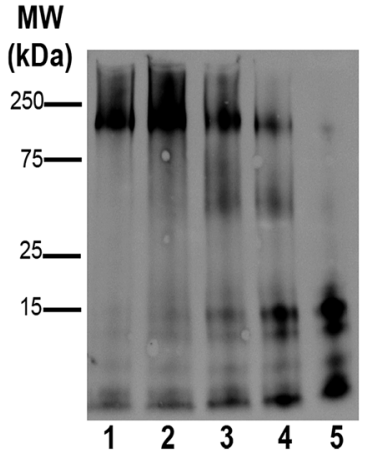

B)

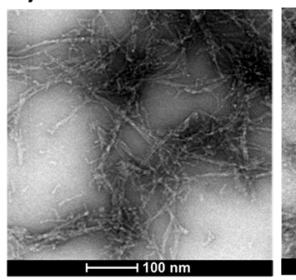

C)

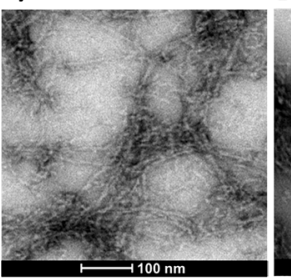

D)

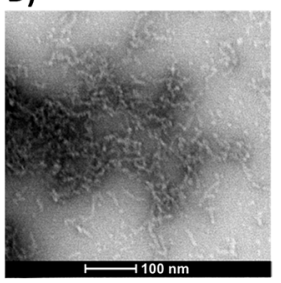

Fig. 7 Influence of FeL1 on the aggregation profile of $A \beta_{1-42}$. (A) Gel electrophoresis/Western blot of $25 \mu \mathrm{M} \mathrm{A} \beta_{1-42}$ and different concentrations of FeL1 in PBS buffer (0.01 M, pH 7.4) after $24 \mathrm{~h}$ incubation with agitation at $37^{\circ} \mathrm{C}$, using anti-A $\beta$ antibody 6 E10. Lane 1 : $A \beta_{1-42}$; lane 2 : $A \beta_{1-42}+$ FeL1 (0.1 equiv.); lane 3: $A \beta_{1-42}+$ FeL1 (0.25 equiv.); lane 4: $A \beta_{1-42}+$ FeL1 ( 0.5 equiv.); lane $5: A \beta_{1-42}+$ FeL1 (1 equiv.). And TEM images of (B) $A \beta_{1-42}$; (C) $A \beta_{1-42}+0.1$ equiv. FeL1; and (D) $A \beta_{1-42}+1$ eq FeL1.

concentration of FeL1 is increased, a reduction in aggregate size is observed, with only small aggregates present with 1 equiv. of FeL1 (Fig. 7D). We also investigated the effect of the free ligand $\mathbf{L 1}$ on $\mathrm{A} \beta_{1-42}$ peptide aggregation. Under the same experimental conditions, $\mathbf{L} 1$ also displays a concentration-dependent effect on aggregation (Fig. S11†), however aggregate species are observed over a broad molecular weight range. We hypothesize that $\mathbf{L 1}$ alters the aggregation pattern via hydrophobic interactions with the $\mathrm{A} \beta$ peptide, ${ }^{19 a, 37,58}$ while the covalent interaction of FeL1 with A $\beta$ His residues results in the preferential formation of low molecular weight species (Fig. 7).

\section{Catalytic antioxidant activity}

FeL1 has been previously reported to exhibit exceptional antioxidant activity for the disproportionation of $\mathrm{H}_{2} \mathrm{O}_{2}$, ${ }^{30 d}$ dismutation of $\mathrm{O}_{2}{ }^{\cdot-},{ }^{30 a}$ and catalytic activity for the decomposition of peroxynitrite ( $\left.\mathrm{PN}, \mathrm{ONOO}^{-}\right) .{ }^{32}$ In addition, the antioxidant activity of FeL1 is maintained, and even enhanced, when bound to albumin, lipoproteins, or imidazole since this minimizes formation of the less catalytically-active $\mu$-oxo iron(Iv) dimer. ${ }^{30 c, 30 d}$ This work highlighted that the FeL1-A $\beta$ species could act as a potent antioxidant, and possibly minimize ROS generation from $\mathrm{A} \beta-\mathrm{Cu}(\mathrm{II})$ when both $\mathrm{FeL1}$ and $\mathrm{Cu}(\mathrm{II})$ are bound to the peptide simultaneously.

Catalase activity. The catalase activity of FeL1 has been demonstrated to exceed that of any other synthetic mimic of the enzyme, ${ }^{30 d, 31,59}$ and its activity increases in the presence of excess imidazole. In order to determine the influence of FeL1 binding to $A \beta_{1-16}$ on its catalase activity, an "Amplex Red" $/ \mathrm{H}_{2} \mathrm{O}_{2}$ catalase assay was performed. This assay relies on competing with the very fast color producing reaction by adding a complex that catalytically decomposes $\mathrm{H}_{2} \mathrm{O}_{2}$. A catalase standard curve (Fig. S12A †) was prepared and different concentrations of FeL1 in the presence and absence of $A \beta_{1-16}$ (Fig. S12B $\dagger$ ) were tested to determine their activity. Both FeL1 and the $1: 1$ FeL1-A $\beta_{1-16}$ adduct displayed good catalase activity, with the latter being superior. This shows that His binding of the A $\beta$ peptide to FeL1 results in an enhancement of catalase activity at all concentrations studied $(1-5 \mu \mathrm{M})$.

$\mathbf{A} \boldsymbol{\beta}-\mathbf{C u}$ (II) ROS production. Under biologically relevant reducing conditions, which are commonly mimicked by reducing agents such as ascorbate (Asc), $\mathrm{A} \beta-\mathrm{Cu}$ (II) species are known to produce an array of ROS composed of superoxide anion radical, hydrogen peroxide, and hydroxyl radical. ${ }^{38 b, 51}$ There are many protocols for investigating the multiple steps that lead to these damaging species (Scheme 3), of which the first one is the oxidation of Asc by $\mathrm{Cu}$ (II). This process was followed by monitoring the time course for disappearance of the Asc absorption band at $265 \mathrm{~nm}$ (Fig. 8) in the presence of $\mathrm{CuCl}_{2}$ and FeL1 only, their binary adducts with $A \beta_{1-16}$, and the ternary adduct formed by combining $A \beta_{1-16}$ with $\mathrm{Cu}(\mathrm{II})$ and FeL1. Consistent with previous reports, ${ }^{51}$ the high rate of Asc consumption in the presence of $\mathrm{Cu}$ (II) is diminished when bound to $A \beta_{1-16}$; and consistent with expectations, both FeL1 and FeL1-A $\beta$ did not promote Asc oxidation. The most revealing result is that the ternary FeL1- $\mathrm{A} \beta_{1-16}-\mathrm{Cu}$ (II) complex displayed only slightly enhanced Asc oxidation in comparison to $\mathrm{A} \beta_{1-16^{-}}$ $\mathrm{Cu}(\mathrm{II})$ only. Overall, and in accordance with the EPR results that show that FeL1 does not alter the $\mathrm{Cu}(\mathrm{II})$ binding site, this assay suggests that the presence of FeL1 does not significantly affect the reduction of $\mathrm{A} \beta-\mathrm{Cu}$ (II) by Asc.

$\mathrm{Cu}-\mathrm{A} \beta$ species can transform $\mathrm{O}_{2}$ to $\mathrm{H}_{2} \mathrm{O}_{2}$ through a series of steps, which can be detected via its reaction with Amplex Red, which forms the intensively colored resorufin (Scheme 3). ${ }^{60}$ Following this process by monitoring the formation of resorufin (Fig. 9A) revealed that: (a) $\mathrm{Cu}$ (II) alone induces the fastest rate of formation of $\mathrm{H}_{2} \mathrm{O}_{2}$; (b) the binding of $\mathrm{Cu}$ (II) to $\mathrm{A} \beta$ slows down the process, as reported previously; ${ }^{61}$ and (c) the ternary FeL1$\mathrm{A} \beta_{1-16}-\mathrm{Cu}$ (II) species shows a reduced rate of $\mathrm{H}_{2} \mathrm{O}_{2}$ formation

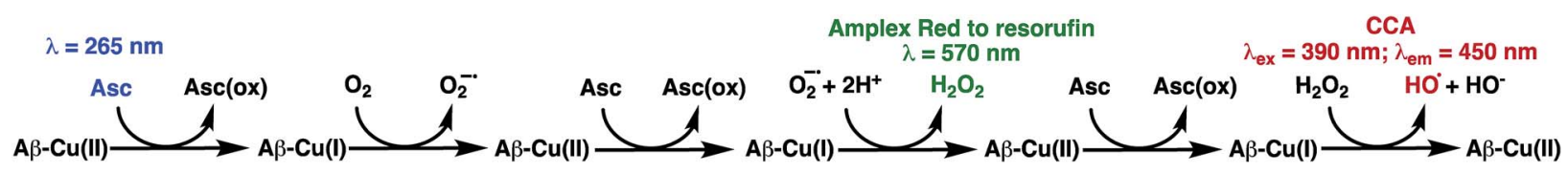

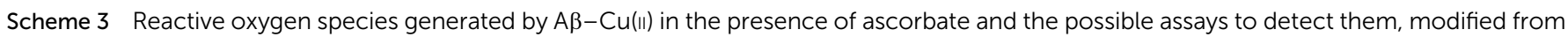
C. Cheignon et al. 2018.38b 


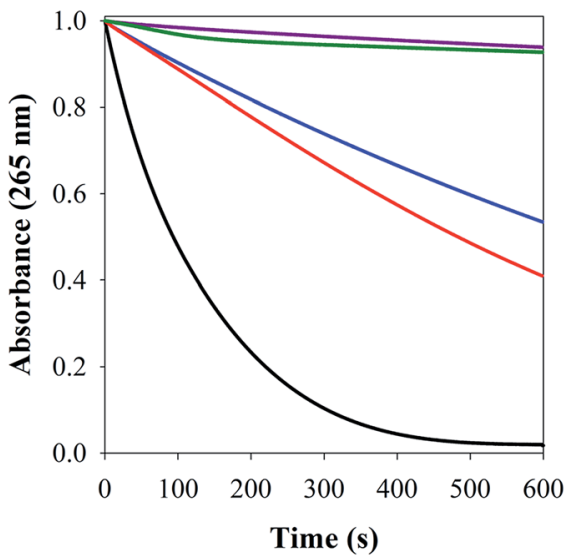

Fig. 8 Ascorbate consumption by $\mathrm{Cu}($ (I) (black), A $\beta-\mathrm{Cu}($ (I) (blue); FeL1$A \beta-C u(॥)$ (red); FeL1-A $\beta$ (purple); FeL1 (green), measured using UV-Vis spectroscopy $(\lambda=265 \mathrm{~nm})$ as a function of time in PBS buffer $(0.01 \mathrm{M}$, $\mathrm{pH}$ 7.4). [Asc $]=100 \mu \mathrm{M},\left[\mathrm{A} \beta_{1-16}\right]=[\mathrm{FeL} 1]=10 \mu \mathrm{M}$ and $\left[\mathrm{CuCl}_{2}\right]=9 \mu \mathrm{M}$.

and lower amount overall. The latter phenomenon is consistent with FeL1 quenching the $\mathrm{H}_{2} \mathrm{O}_{2}$ that is produced by the bound $\mathrm{Cu}(\mathrm{II})$, due to the good catalase-like activity of FeL1 in both its
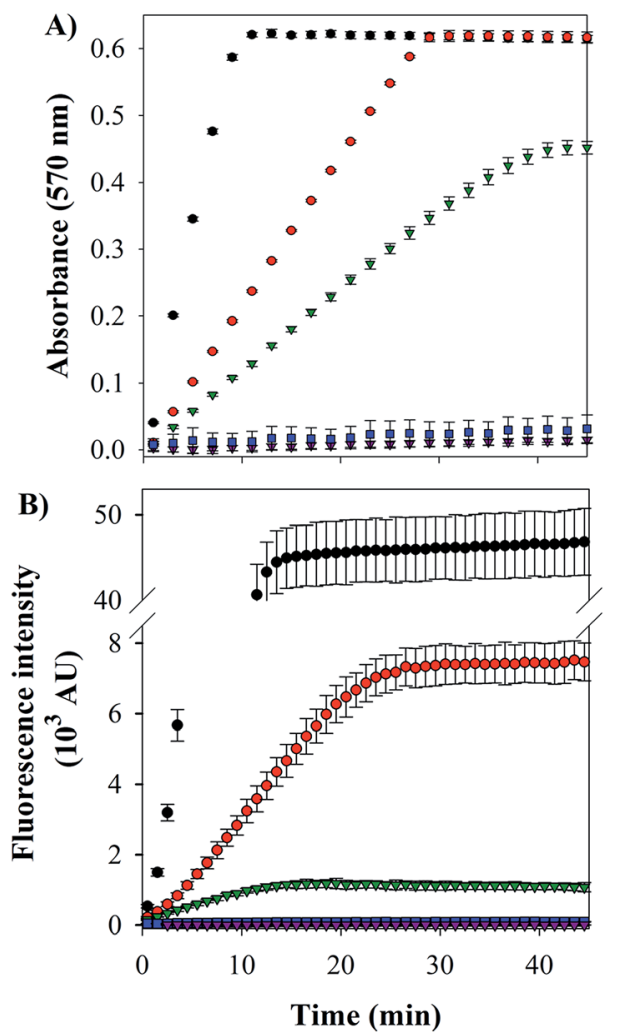

Fig. 9 ROS production by $\mathrm{A} \beta-\mathrm{Cu}(\mathrm{II})$ in the presence of ascorbate. (A) Amplex red assay for $\mathrm{H}_{2} \mathrm{O}_{2}$ formation by UV-Vis absorbance at $570 \mathrm{~nm}$. $[$ Asc $]=400 \mu \mathrm{M},\left[\mathrm{A} \beta_{1-16}\right]=[\mathrm{FeL} 1]=[\mathrm{Cu}(\mathrm{II})]=20 \mu \mathrm{M},[$ Amplex red $]=100$ $\mu \mathrm{M} ;[\mathrm{HRP}]=0.4 \mathrm{U} \mathrm{mL}^{-1}$ (where 1 unit is defined as the amount of enzyme that will form $1.0 \mathrm{mg}$ purpurogallin from pyrogallol in 20 seconds at $\mathrm{pH} 6.0$ at $20{ }^{\circ} \mathrm{C}$ ). (B) $\mathrm{CCA}$ assay for $\cdot \mathrm{OH}$ formation measured by fluorescence, $\lambda_{\mathrm{ex}} 395 \mathrm{~nm}$ and $\lambda_{\mathrm{em}} 450 \mathrm{~nm}$. [Asc] $=300$ $\mu \mathrm{M},\left[\mathrm{A} \beta_{1-16}\right]=[\mathrm{FeL} 1]=[\mathrm{Cu}(\mathrm{I})]=40 \mu \mathrm{M},[\mathrm{CCA}]=100 \mu \mathrm{M} . \bullet \mathrm{Cu}(\mathrm{II}) ; \mathrm{OA} \beta-$ $\mathrm{Cu}(\mathrm{II}) ; \nabla \mathrm{FeL} 1-\mathrm{A} \beta-\mathrm{Cu}(\mathrm{II}) ; \nabla \mathrm{FeL} 1-\mathrm{A} \beta ; \square \mathrm{FeL} 1$. free form and when bound to the $\mathrm{A} \beta$ peptide (Fig. $\mathrm{S} 12 \mathrm{~B} \dagger$ ). In addition to catalase activity, FeL1 displays exceptional antioxidant activity for the dismutation of $\mathrm{O}_{2}{ }^{-{ }^{-}},{ }^{30 a}$ and thus the complex may also quench superoxide formed as shown in Scheme 3. Detection of this reactivity using a cytochrome c assay $^{\mathbf{9 b , 1 7 b}}$ was challenging due to interference of FeL1 absorption bands.

The last and most damaging step in Scheme 3 occurs via the formation of the hydroxyl radical $(\cdot \mathrm{OH})$ from the reaction of $\mathrm{Cu}\left(\mathrm{I}\right.$ ) with $\mathrm{H}_{2} \mathrm{O}_{2}$ (Scheme 3), which may be detected by the reaction of 3-coumarin carboxylic acid (3-CCA) with $\cdot \mathrm{OH}$ to form the fluorescent 7-hydroxy-3-coumarin-carboxylic acid (7$\mathrm{OH}-3-\mathrm{CCA}) .^{62}$ Consistent with previous reports, ${ }^{12 e} \cdot \mathrm{OH}$ production is quite fast and significant for $\mathrm{A} \beta-\mathrm{Cu}(\mathrm{II})$ albeit much less than for non-His-coordinated $\mathrm{Cu}(\mathrm{II})$ (Fig. 9B). The addition of FeL1, to form the ternary FeL1-A $\beta_{1-16}-\mathrm{Cu}$ (II) species, resulted in a further 6-fold reduction in the amount of 7-OH-3-CCA. In principle, this may reflect either the lower availability of $\mathrm{H}_{2} \mathrm{O}_{2}$ due to the catalase-like activity or the direct quenching of $\cdot \mathrm{OH}$ by FeL1, or a combination of both. Another possible interpretation is that $\mathrm{Cu}$ in the ternary complex is less reactive, which is unlikely considering the minimal interaction of FeL1 with $\mathrm{A} \beta_{1-}$ ${ }_{16}-\mathrm{Cu}(\mathrm{II})$ binding motif. In any case, the almost complete elimination of hydroxyl radical formation demonstrates that the potent antioxidant activity of FeL1 is maintained when bound to the $\mathrm{A} \beta$ peptide.

\section{Summary}

This study underlines the ability of FeL1 to target both $\mathrm{A} \beta$ peptide aggregation and ROS formation, two factors influencing AD progression. FeL1 and the free corrole ligand $\mathbf{L 1}$ influence A $\beta$ aggregation differently; FeL1 stabilizes low molecular weight species while L1 stabilizes aggregates over a broad MW range. FeL1 forms a $1: 1$ adduct with $\mathrm{A} \beta$ via axial binding of one His residue with a moderate binding affinity $\left(K_{\mathrm{d}}\right.$ of $\left.\sim 10^{-7} \mathrm{M}\right)$, which is weaker in comparison to $\mathrm{Cu}$ binding to $\mathrm{A} \beta\left(K_{\mathrm{d}}\right.$ of $\left.\sim 10^{-10} \mathrm{M}\right)$ but still stronger than $\mathrm{Zn}$ (II) binding $\left(K_{\mathrm{d}}\right.$ of $\left.\sim 10^{-5} \mathrm{M}\right) .{ }^{\mathbf{1 0 b}, \mathbf{1 4 a}, \mathbf{3 8 a}, 51}$ It is interesting to note that FeL1 has a much higher affinity for A $\beta$ peptide His residues than 1-MeIm or free His, suggesting significant non-covalent interactions between FeL1 and the A $\beta$ peptide. These results are in agreement with the specific binding of FeL1 to HDL2 proteins in comparison to other serum constituents, due to the amphipolar character of FeL1. ${ }^{30 c}$ Indeed, $\mathbf{L} \mathbf{1}$ was also shown to influence $\mathrm{A} \beta$ peptide aggregation likely due to hydrophobic interactions, albeit to a significantly lower extent. In a similar manner, non-covalent $\pi-\pi$ stacking interactions, in addition to covalent binding, have been shown to dictate the association of $\mathrm{Pt}(\mathrm{II})$ (phenanthroline) complexes with the $\mathrm{A} \beta$ peptide. ${ }^{21 a, 29,63}$

We have also shown herein that FeL1 binds to the A $\beta$ peptide concurrently with $\mathrm{Cu}$ (II). Our EPR data suggests no significant change in the Cu-binding site with FeL1 His coordination. This is further corroborated by the ascorbate oxidation assay, which displays only minor changes to the rate of ascorbate oxidation for $\mathrm{A} \beta-\mathrm{Cu}$ (II) and the ternary species FeL1-A $\beta-\mathrm{Cu}$ (II). However, the bound FeL1 acts as an efficient catalase, and decomposes 
a significant fraction of the $\mathrm{H}_{2} \mathrm{O}_{2}$ generated by $\mathrm{A} \beta-\mathrm{Cu}$ (II) (Fig. 9A). In the presence of FeL1 we also observe a decrease in the formation of $\cdot \mathrm{OH}$ (Fig. 9B), consistent with the result from the amplex red assay. Our results show that amphipolar FeL1 binds specifically to the $A \beta$ peptide via a His residue in a $1: 1$ stoichiometry, and this interaction modulates the peptide aggregation pathway. In addition, the peptide-bound FeL1 maintains its exceptional antioxidant activity, limiting ROS formation from $\mathrm{A} \beta-\mathrm{Cu}(\mathrm{II})$. Overall, our results highlight the promising multifunctional character of FeL1 to limit A $\beta$ peptide aggregation and the formation of damaging ROS, two hallmarks of $\mathrm{AD}$.

\section{Conflicts of interest}

There are no conflicts to declare.

\section{Acknowledgements}

This work was supported by Natural Sciences and Engineering Research Council (NSERC) Discovery Grant (T. S., M. A. S., and C. J. W.), a Michael Smith Career Investigator Award (T. S.), and a New Investigator Grant from the Alzheimer's Association (NIRG-15-362537), Brain Canada (to T. S.) and Science without borders (CAPES - Proc. no. 0711/13-6, Brazil to L. M. F. G.). Dr Andrew Lewis is thanked for assistance with NMR measurements. K. E. P. acknowledges a NSERC Vanier CGS for support. Z. G. and A. M. acknowledge The Israel Science Foundation for support.

\section{Notes and references}

1 A. W. Martin Prince, M. Guerchet, G.-C. Ali, Yu-T. Wu and M. Prina, World Alzheimer Report 2015, The Global Impact on Dementia. An Analysis of Prevalence, Incidence, Cost and Trends, 2015.

2 Dementia statistics, http://www.alz.co.uk/research/statistics, accessed May 24th.

3 (a) V. H. Finder, J. Alzheimer's Dis., 2010, 22, S5-S19; (b) E. D. Roberson and L. Mucke, Science, 2006, 314, 781-784; (c) P. A. Adlard, S. A. James, A. I. Bush and C. L. Masters, Drugs Today, 2009, 45, 293-304; (d) M. Citron, Nat. Rev. Drug Discovery, 2010, 9, 387-398; (e) D. J. Selkoe, Nat. Med., 2011, 17, 1693.

4 J. L. Hickey and P. S. Donnelly, Coord. Chem. Rev., 2012, 256, 2367-2380.

5 H. W. Querfurth and F. M. LaFerla, N. Engl. J. Med., 2010, 362, 329-344.

6 M. P. Mazanetz and P. M. Fischer, Nat. Rev. Drug Discovery, 2007, 6, 464-479.

7 (a) G. K. W. Kong, J. J. Adams, H. H. Harris, J. F. Boas, C. C. Curtain, D. Galatis, C. L. Masters, K. J. Barnham, W. J. McKinstry, R. Cappai and M. W. Parker, J. Mol. Biol., 2007, 367, 148-161; (b) D. J. Selkoe and D. Schenk, Annu. Rev. Pharmacol. Toxicol., 2003, 43, 545-584.
8 C. A. McLean, R. A. Cherny, F. W. Fraser, S. J. Fuller, M. J. Smith, K. Beyreuther, A. I. Bush and C. L. Masters, Ann. Neurol., 1999, 46, 860-866.

9 (a) C. L. Masters, G. Simms, N. A. Weinman, G. Multhaup, B. L. McDonald and K. Beyreuther, Proc. Natl. Acad. Sci. U. S. A., 1985, 82, 4245-4249; (b) M. Mital, E. Wezynfeld Nina, T. Fraczyk, Z. Wiloch Magdalena, E. Wawrzyniak Urszula, A. Bonna, C. Tumpach, J. Barnham Kevin, L. Haigh Cathryn, W. Bal and C. Drew Simon, Angew. Chem., Int. Ed., 2015, 54, 10460-10464; (c) V. Borghesani, B. Alies and C. Hureau, Eur. J. Inorg. Chem., 2018, 2018, 7-15.

10 (a) D. J. Selkoe and J. Hardy, EMBO Mol. Med., 2016, 8, 595608; (b) M. C. Heffern, P. T. Velasco, L. M. Matosziuk, J. L. Coomes, C. Karras, M. A. Ratner, W. L. Klein, A. L. Eckermann and T. J. Meade, ChemBioChem, 2014, 15, 1584-1589; (c) S. Lesne, M. T. Koh, L. Kotilinek, R. Kayed, C. G. Glabe, A. Yang, M. Gallagher and K. H. Ashe, Nature, 2006, 440, 352-357; (d) A. D. Watt, V. L. Villemagne and K. J. Barnham, J. Alzheimer's Dis., 2013, 33(suppl. 1), S283S293.

11 D. H. Cho, T. Nakamura, J. G. Fang, P. Cieplak, A. Godzik, Z. Gu and S. A. Lipton, Science, 2009, 324, 102-105.

12 (a) E. Nam, J. Han, J.-M. Suh, Y. Yi and M. H. Lim, Curr. Opin. Chem. Biol., 2018, 43, 8-14; (b) S. C. Drew and K. J. Barnham, Acc. Chem. Res., 2011, 44, 1146-1155; (c) E. Gaggelli, H. Kozlowski, D. Valensin and G. Valensin, Chem. Rev., 2006, 106, 1995-2044; (d) J. A. Duce and A. I. Bush, Prog. Neurobiol., 2010, 92, 1-18; (e) C. Cheignon, M. Jones, E. Atrian-Blasco, I. Kieffer, P. Faller, F. Collin and C. Hureau, Chem. Sci., 2017, 8, 5107-5118; (f) Y. Yuan, F. Niu, Y. Liu and N. Lu, Neurol. Sci., 2014, 35, 923-928.

13 (a) M. G. Savelieff, S. Lee, Y. Liu and M. H. Lim, ACS Chem. Biol., 8, 856-865; (b) K. P. Kepp, Chem. Rev., 2012, 112, 5193-5239; (c) T. D. Rae, P. J. Schmidt, R. A. Pufahl, V. C. Culotta and T. V. O'Halloran, Science, 1999, 284, 805808.

14 (a) F. Hane and Z. Leonenko, Biomolecules, 2014, 4, 101-116; (b) C. C. Curtain, F. Ali, I. Volitakis, R. A. Cherny, R. S. Norton, K. Beyreuther, C. J. Barrow, C. L. Masters, A. I. Bush and K. J. Barnham, J. Biol. Chem., 2001, 276, 20466-20473; (c) R. J. Ward, D. T. Dexter and R. R. Crichton, J. Trace Elem. Med. Biol., 2015, 31, 267-273.

15 (a) M. A. Lovell, J. D. Robertson, W. J. Teesdale, J. L. Campbell and W. R. Markesbery, J. Neurosci., 1998, 158, 47-52; (b) L. M. Miller, Q. Wang, T. P. Telivala, R. J. Smith, A. Lanzirotti and J. Miklossy, J. Struct. Biol., 2006, 155, 30-37; (c) R. Squitti, Front. Biosci., 2012, 17, 451-472; (d) A. S. Pithadia and M. H. Lim, Curr. Opin. Chem. Biol., 2012, 67-73; (e) P. Faller and C. Hureau, Dalton Trans., 2009, 1080-1094, DOI: 10.1039/b813398k.

16 (a) A. Lakatos, B. Gyurcsik, N. V. Nagy, Z. Csendes, E. Weber, L. Fulop and T. Kiss, Dalton Trans., 2012, 41, 1713-1726; (b) S. L. Leong, T. R. Young, K. J. Barnham, A. G. Wedd, M. G. Hinds, Z. Xiao and R. Cappai, Metallomics, 2014, 6, 105-116; (c) A. S. Pithadia, A. Kochi, M. T. Soper, M. W. Beck, Y. Z. Liu, S. Lee, A. S. DeToma, B. T. Ruotolo and M. H. Lim, Inorg. Chem., 2012, 51, 12959-12967; (d) 
F. Bousejra-ElGarah, C. Bijani, Y. Coppel, P. Faller and C. Hureau, Inorg. Chem., 2011, 50, 9024-9030.

17 (a) D. Pramanik, C. Ghosh and S. G. Dey, J. Am. Chem. Soc., 2011, 133, 15545-15552; (b) K. Reybier, S. Ayala, B. Alies, J. V. Rodrigues, S. B. Rodriguez, G. L. Penna, F. Collin, C. M. Gomes, C. Hureau and P. Faller, Angew. Chem., Int. Ed., 2016, 55, 1085-1089; (c) X. Huang, M. P. Cuajungco, C. S. Atwood, M. A. Hartshorn, J. D. A. Tyndall, G. R. Hanson, K. C. Stokes, M. Leopold, G. Multhaup, L. E. Goldstein, R. C. Scarpa, A. J. Saunders, J. Lim, R. D. Moir, C. Glahe, E. F. Bowden, C. L. Masters, D. P. Fairlie, R. E. Tanzi and A. I. Bush, J. Biol. Chem., 1999, 274, 37111-37116; (d) G. F. Z. da Silva and L. J. Ming, Angew. Chem., Int. Ed., 2005, 44, 5501-5504; (e) X. Huang, C. S. Atwood, M. A. Hartshorn, G. Multhaup, L. E. Goldstein, R. C. Scarpa, M. P. Cuajungco, D. N. Gray, J. Lim, R. D. Moir, R. E. Tanzi and A. I. Bush, Biochemistry, 1999, 38, 7609-7616; (f) C. Cheignon, P. Faller, D. Testemale, C. Hureau and F. Collin, Metallomics, 2016, 8, 1081-1089.

18 (a) M. G. Savelieff, A. S. DeToma, J. S. Derrick and M. H. Lim, Acc. Chem. Res., 2014, 47, 2475-2482; (b) M. C. Carreiras, E. Mendes, M. J. Perry, A. P. Francisco and J. MarcoContelles, Curr. Top. Med. Chem., 2013, 13, 1745-1770; (c) Z. Liu, A. Zhang, H. Sun, Y. Han, L. Kong and X. Wang, RSC Adv., 2017, 7, 6046-6058.

19 (a) L. M. F. Gomes, R. P. Vieira, M. R. Jones, M. C. P. Wang, C. Dyrager, E. M. Souza-Fagundes, J. G. Da Silva, T. Storr and H. Beraldo, J. Inorg. Biochem., 2014, 139, 106-116; (b) L. Hao, Q. Yunwei and W. Xiaohui, Future Med. Chem., 2018, 10, 679701; (c) M. R. Jones, E. L. Service, J. R. Thompson, M. C. P. Wang, I. J. Kimsey, A. S. DeToma, A. Ramamoorthy, M. H. Lim and T. Storr, Metallomics, 2012, 4, 910-920; (d) X. Wang, X. Wang and Z. Guo, Coord. Chem. Rev., 2018, 362, 72-84; (e) S. Lee, X. Zheng, J. Krishnamoorthy, M. G. Savelieff, H. M. Park, J. R. Brender, J. H. Kim, J. S. Derrick, A. Kochi, H. J. Lee, C. Kim, A. Ramamoorthy, M. T. Bowers and M. H. Lim, J. Am. Chem. Soc., 2014, 136, 299-310.

20 (a) J. J. Miller, L. M. F. Gomes, T. Storr and A. Casini, The Interaction of Metal Compounds with Protein Targets: New Tools in Medicinal Chemistry and Chemical Biology, in Encyclopedia of Inorganic and Bioinorganic Chemistry, John Wiley \& Sons, Ltd, 2017, DOI: 10.1002/ 9781119951438.eibc2499; (b) K. Chen and M. Cui, MedChemComm, 2017, 8, 1393-1407; (c) D. J. Hayne, S. Lim and P. S. Donnelly, Chem. Soc. Rev., 2014, 43, 6701-6715.

21 (a) K. J. Barnham, V. B. Kenche, G. D. Ciccotosto, D. P. Smith, D. J. Tew, X. Liu, K. Perez, G. A. Cranston, T. J. Johanssen, I. Volitakis, A. I. Bush, C. L. Masters, A. R. White, J. P. Smith, R. A. Cherny and R. Cappai, Proc. Natl. Acad. Sci. U. S. A., 2008, 105, 6813-6818; (b) I. Sasaki, C. Bijani, S. Ladeira, V. Bourdon, P. Faller and C. Hureau, Dalton Trans., 2012, 41, 6404-6407; (c) V. A. Streltsov, V. Chandana Epa, S. A. James, Q. I. Churches, J. M. Caine, V. B. Kenche and K. J. Barnham, Chem. Commun., 2013, 49, 11364-11366; (d) F. Collin, I. Sasaki, H. Eury, P. Faller and C. Hureau, Chem. Commun., 2013, 49, 2130-2132.
22 (a) M. R. Jones, C. Mu, M. C. P. Wang, M. I. Webb, C. J. Walsby and T. Storr, Metallomics, 2015, 7, 129-135; (b) L. Messori, M. Camarri, T. Ferraro, C. Gabbiani and D. Franceschini, ACS Med. Chem. Lett., 2013, 4, 329-332.

23 (a) G. S. Yellol, J. G. Yellol, V. B. Kenche, X. M. Liu, K. J. Barnham, A. Donaire, C. Janiak and J. Ruiz, Inorg. Chem., 2015, 54, 470-475; (b) L. Lu, H.-J. Zhong, M. Wang, S.-L. Ho, H.-W. Li, C.-H. Leung and D.-L. Ma, Sci. Rep., 2015, 5, 14619.

24 (a) J. Suh, S. H. Yoo, M. G. Kim, K. Jeong, J. Y. Ahn, M.-s. Kim, P. S. Chae, T. Y. Lee, J. Lee, J. Lee, Y. A. Jang and E. H. Ko, Angew. Chem., Int. Ed., 2007, 46, 7064-7067; (b) J. S. Derrick, J. Lee, S. J. C. Lee, Y. Kim, E. Nam, H. Tak, J. Kang, M. Lee, S. H. Kim, K. Park, J. Cho and M. H. Lim, J. Am. Chem. Soc., 2017, 139, 2234-2244.

25 C. Y. Chan, A. Noor, C. A. McLean, P. S. Donnelly and P. J. Barnard, Chem. Commun., 2017, 53, 2311-2314.

26 B. Y.-W. Man, H.-M. Chan, C.-H. Leung, D. S.-H. Chan, L.-P. Bai, Z.-H. Jiang, H.-W. Li and D.-L. Ma, Chem. Sci., 2011, 2, 917-921.

27 (a) C. D. Amandine, A. Vinita, G. Régis, D. Nicolas, P. Clotilde and H. Christelle, Chem.-Eur. J., 2018, 24, 5095-5099; (b) R. Walke Gulshan, S. Ranade Dnyanesh, M. Bapat Archika, R. Srikanth and P. Kulkarni Prasad, ChemistrySelect, 2016, 1, 3497-3501.

28 L. He, X. Wang, D. Zhu, C. Zhao and W. Du, Metallomics, 2015, 7, 1562-1572.

29 V. B. Kenche, L. W. Hung, K. Perez, I. Volitakes, G. Ciccotosto, J. Kwok, N. Critch, N. Sherratt, M. Cortes, V. Lal, C. L. Masters, K. Murakami, R. Cappai, P. A. Adlard and K. J. Barnham, Angew. Chem., Int. Ed., 2013, 52, 33743378.

30 (a) M. Eckshtain, I. Zilbermann, A. Mahammed, I. Saltsman, Z. Okun, E. Maimon, H. Cohen, D. Meyerstein and Z. Gross, Dalton Trans., 2009, 7879-7882, DOI: 10.1039/b911278b; (b) Z. Gross, G. Golubkov and L. Simkhovich, Angew. Chem., Int. Ed., 2000, 4045-4047; (c) A. Haber, M. Aviram and Z. Gross, Chem. Sci., 2011, 2, 295-302; (d) A. Mahammed and Z. Gross, Chem. Commun., 2010, 46, 7040-7042; (e) Z. Okun and Z. Gross, Inorg. Chem., 2012, 51, 8083-8090.

31 A. Mahammed and Z. Gross, J. Am. Chem. Soc., 2005, 127, 2883-2887.

32 A. Mahammed and Z. Gross, Angew. Chem., Int. Ed., 2006, 45, 6544-6547.

33 A. Haber, A. Mahammed, B. Fuhrman, N. Volkova, R. Coleman, T. Hayek, M. Aviram and Z. Gross, Angew. Chem., Int. Ed., 2008, 47, 7896-7900.

34 (a) C. Ghosh, M. Seal, S. Mukherjee and S. Ghosh Dey, Acc. Chem. Res., 2015, 48, 2556-2564; (b) M. Seal, S. Mukherjee and S. G. Dey, Metallomics, 2016, 8, 1266-1272; (c) S. Mukherjee, M. Seal and S. G. Dey, J. Biol. Inorg Chem., 2014, 19, 1355-1365.

35 A. Haber, M. Aviram and Z. Gross, Inorg. Chem., 2012, 51, 2830.

36 P. Lim, A. Mahammed, Z. Okun, I. Saltsman, Z. Gross, H. B. Gray and J. Termini, Chem. Res. Toxicol., 2012, 25, 400-409. 
37 A. Mahammed, H. B. Gray, J. J. Weaver, K. Sorasaenee and Z. Gross, Bioconjugate Chem., 2004, 15, 738-746.

38 (a) L. Q. Hatcher, L. Hong, W. D. Bush, T. Carducci and J. D. Simon, J. Phys. Chem. B, 2008, 112, 8160-8164; (b) C. Cheignon, M. Tomas, D. Bonnefont-Rousselot, P. Faller, C. Hureau and F. Collin, Redox Biol., 2018, 14, 450-464; (c) B. Alies, A. Conte-Daban, S. Sayen, F. Collin, I. Kieffer, E. Guillon, P. Faller and C. Hureau, Inorg. Chem., 2016, 55, 10499-10509; (d) I. Zawisza, M. Rózga and W. Bal, Coord. Chem. Rev., 2012, 256, 2297-2307.

39 D. Valensin, P. Anzini, E. Gaggelli, N. Gaggelli, G. Tamasi, R. Cini, C. Gabbiani, E. Michelucci, L. Messori, H. Kozlowski and G. Valensin, Inorg. Chem., 2010, 49, 4720-4722.

40 (a) Y. Miller, B. Ma and R. Nussinov, Coord. Chem. Rev., 2012, 256, 2245-2252; (b) V. Wineman-Fisher, D. N. Bloch and Y. Miller, Coord. Chem. Rev., 2016, 327-328, 20-26; (c) S. Parthasarathy, F. Long, Y. Miller, Y. Xiao, D. McElheny, K. Thurber, B. Ma, R. Nussinov and Y. Ishii, J. Am. Chem. Soc., 2011, 133, 3390-3400; (d) Y. Miller, B. Ma and R. Nussinov, Proc. Natl. Acad. Sci. U. S. A., 2010, 107, 94909495.

41 L. Alderighi, P. Gans, A. Ienco, D. Peters, A. Sabatini and A. Vacca, Coord. Chem. Rev., 1999, 184, 311-318.

42 (a) C. A. Joseph and P. C. Ford, J. Am. Chem. Soc., 2005, 127, 6737-6743; (b) E. Van Caemelbecke, S. Will, M. Autret, V. A. Adamian, J. Lex, J.-P. Gisselbrecht, M. Gross, E. Vogel and K. M. Kadish, Inorg. Chem., 1996, 35, 184-192; (c) E. Vogel, S. Will, A. S. Tilling, L. Neumann, J. Lex, E. Bill, A. X. Trautwein and K. Wieghardt, Angew. Chem., Int. Ed., 1994, 33, 731-735.

43 F. A. Walker, M.-W. Lo and M. T. Ree, J. Am. Chem. Soc., 1976, 98, 5552-5560.

44 D. Sellmann, S. Emig and F. W. Heinemann, Angew. Chem., Int. Ed., 1997, 36, 1734-1736.

45 P. Gans, A. Sabatini and A. Vacca, Ann. Chim., 1999, 89, 4549.

46 T. Kowalik-Jankowska, M. Ruta, K. Wiśniewska and L. Łankiewicz, J. Inorg. Biochem., 2003, 95, 270-282.

47 (a) A. E. Martell and R. D. Hancock, Metal Complexes in Aqueous Solutions, Plenum Press, New York, 1996; (b) J.-S. Choi, J. J. Braymer, R. P. R. Nanga, A. Ramamoorthy and M. H. Lim, Proc. Natl. Acad. Sci. U. S. A., 2010, 107, 21990-21995; (c) W. R. Harris, C. J. Carrano and K. N. Raymond, J. Am. Chem. Soc., 1979, 101, 2722-2727.

48 Z. Xiao and A. G. Wedd, Nat. Prod. Rep., 2010, 27, 768-789. 49 T. S. Choi, H. J. Lee, J. Y. Han, M. H. Lim and H. I. Kim, J. Am. Chem. Soc., 2017, 139, 15437-15445.

50 H. Eury, C. Bijani, P. Faller and C. Hureau, Angew. Chem., Int. Ed. Engl., 2011, 50, 901-905.
51 E. Atrián-Blasco, M. del Barrio, P. Faller and C. Hureau, Anal. Chem., 2018, 90, 5909-5915.

52 (a) B. Alies, I. Sasaki, O. Proux, S. Sayen, E. Guillon, P. Faller and C. Hureau, Chem. Commun., 2013, 49, 1214-1216; (b) S. C. Drew, C. J. Noble, C. L. Masters, G. R. Hanson and K. J. Barnham, J. Am. Chem. Soc., 2009, 131, 1195-1207; (c) C. Hureau and P. Dorlet, Coord. Chem. Rev., 2012, 256, 2175-2187.

53 G. Palmer, Iron Porphyrins. Part II, Addison-Wesley Publ. Co., Reading, MA, 1983.

54 (a) S. Cai, S. Licoccia and F. A. Walker, Inorg. Chem., 2001, 40, 5795-5798; (b) L. Simkhovich, I. Goldberg and Z. Gross, Inorg. Chem., 2002, 41, 5433-5439.

55 L. V. Liu, S. Hong, J. Cho, W. Nam and E. I. Solomon, J. Am. Chem. Soc., 2013, 135, 3286-3299.

56 (a) D. M. Walsh and D. J. Selkoe, J. Neurochem., 2007, 101, 1172-1184; (b) C. Haass and D. J. Selkoe, Nat. Rev. Mol. Cell Biol., 2007, 8, 101-112; (c) Y. S. Gong, L. Chang, K. L. Viola, P. N. Lacor, M. P. Lambert, C. E. Finch, G. A. Krafft and W. L. Klein, Proc. Natl. Acad. Sci. U. S. A., 2003, 100, 10417-10422; (d) R. Jakob-Roetne and H. Jacobsen, Angew. Chem., Int. Ed., 2009, 48, 3030-3059.

57 M. R. Jones, E. Mathieu, C. Dyrager, S. Faissner, Z. Vaillancourt, K. J. Korshavn, M. H. Lim, A. Ramamoorthy, V. Wee Yong, S. Tsutsui, P. K. Stys and T. Storr, Chem. Sci., 2017, 8, 5636-5643.

58 (a) H. Kroth, A. Ansaloni, Y. Varisco, A. Jan, N. Sreenivasachary, N. Rezaei-Ghaleh, V. Giriens, S. Lohmann, M. P. Lopez-Deber, O. Adolfsson, M. Pihlgren, P. Paganetti, W. Froestl, L. Nagel-Steger, D. Willbold, T. Schrader, M. Zweckstetter, A. Pfeifer, H. A. Lashuel and A. Muhs, J. Biol. Chem., 2012, 287, 34786-34800; (b) M. G. Savelieff, Y. Liu, R. R. P. Senthamarai, K. J. Korshavn, H. J. Lee, A. Ramamoorthy and M. H. Lim, Chem. Commun., 2014, 50, 5301-5303.

59 A. Mahammed and Z. Gross, Catal. Sci. Technol., 2011, 1, 535-540.

60 M. Zhou, Z. Diwu, N. Panchuk-Voloshina and R. P. Haugland, Anal. Biochem., 1997, 253, 162-168.

61 S. Chassaing, F. Collin, P. Dorlet, J. Gout, C. Hureau and P. Faller, Curr. Top. Med. Chem., 2012, 12, 2573-2595.

62 M. Jensen, A. Canning, S. Chiha, P. Bouquerel, J. T. Pedersen, J. Østergaard, O. Cuvillier, I. Sasaki, C. Hureau and P. Faller, Chem.-Eur. J., 2012, 18, 4836-4839. 63 (a) S. G. Yao, R. A. Cherny, A. I. Bush, C. L. Masters and K. J. Barnham, J. Pept. Sci., 2004, 10, 210-217; (b) G. Ma, F. Huang, X. Pu, L. Jia, T. Jiang, L. Li and Y. Liu, Chem.Eur. J., 2011, 17, 11657-11666; (c) M. Turner, J. A. Platts and R. J. Deeth, J. Chem. Theory Comput., 2016, 12, 13851392. 